\title{
Alterations in regulatory T-cells: Rediscovered pathways in immunotoxicology
}

\author{
Emanuela Corsini ${ }^{1}$, Mohamed Oukka ${ }^{2}$, Raymond Pieters ${ }^{3}$, Nancy I. Kerkvliet ${ }^{4}$, Rafael \\ Ponce $^{5}$, and Dori R. Germolec ${ }^{6}$
}

${ }^{1}$ Laboratory of Toxicology, Department of Pharmacological Sciences, Università degli Studi di Milano, Italy ${ }^{2}$ Center for Neurologic Diseases, Brigham and Women's Hospital, Harvard Medical School, Boston, MA, USA ${ }^{3}$ Institute for Risk Assessment Sciences, Immunotoxicology, Utrecht University and Research Centre Technology and Innovation, Utrecht University of Applied Sciences, Utrecht, the Netherlands ${ }^{4}$ Department of Environmental and Molecular Toxicology, Oregon State University, Corvallis, OR, USA ${ }^{5}$ Amgen, Inc., Seattle, WA, USA ${ }^{6}$ National Toxicology Program, National Institute of Environmental Health Sciences, NIH, RTP, NC, USA

\section{Abstract}

In addition to the effector T-cells subsets, T-cells can also differentiate into cells that play a suppressive or regulatory role in adaptive immune responses. The cell types currently identified as regulatory T-cells $\left(\mathrm{T}_{\text {regs }}\right)$ include natural or thymic-derived $\mathrm{T}_{\text {regs }}, \mathrm{T}$-cells which express Foxp $3^{+} \mathrm{CD} 25^{+} \mathrm{CD}^{+}$and can suppress immune responses to autoreactive T-cells, as well as inducible $\mathrm{T}_{\text {regs }}$, that are generated from naïve $\mathrm{T}$-cells in the periphery after interaction with antigens presented by dendritic cells. Inducible $\mathrm{T}_{\text {regs }}$ include $\mathrm{T}_{\mathrm{H}} 3$ cells, $\mathrm{T}_{\mathrm{r}} 1$ cells, and Foxp $3^{+}-$ inducible $T_{\text {regs }} . T_{\text {regs }}$ have been shown to be critical in the maintenance of immune responses and $\mathrm{T}$-cell homeostasis. These cells play an important role in suppressing responses to self-antigens and in controlling inappropriate responses to non-self-antigens, such as commensal bacteria or food in the gut. For example, depletion of $\mathrm{CD} 4^{+} \mathrm{CD} 25^{+} \mathrm{T}_{\text {regs }}$ from mice resulted in the development of multi-organ autoimmune diseases. $\mathrm{CD} 4^{+} \mathrm{CD} 25^{+} \mathrm{T}_{\text {regs }}$ and/or IL-10-producing $\mathrm{T}_{\mathrm{r}} 1$ cells are capable of suppressing or attenuating $\mathrm{T}_{\mathrm{H}} 2$ responses to allergens. Moreover, adoptive transfer of $\mathrm{CD} 4^{+} \mathrm{CD} 25^{+} \mathrm{T}_{\text {regs }}$ from healthy to diseased animals resulted in the prevention or cure of certain autoimmune diseases, and was able to induce transplantation tolerance. Clinical improvement seen after allergen immunotherapy for allergic diseases such as rhinitis and asthma is associated with the induction of IL-10- and TGF $\beta$-producing $\mathrm{T}_{\mathrm{r}} 1$ cells as well as FoxP3expressing IL-10 T-cells, with resulting suppression of the $\mathrm{T}_{\mathrm{H}} 2$ cytokine milieu. Activation, expansion, or suppression of $\mathrm{CD} 4{ }^{+} \mathrm{CD} 25^{+} \mathrm{T}_{\text {regs }}$ in vivo by xenobiotics, including drugs, may therefore represent a relevant mechanism underlying immunotoxicity, including immunosuppression, allergic asthma, and autoimmune diseases.

\section{(C) 2011 Informa Healthcare USA, Inc.}

Address for Correspondence: Prof. Emanuela Corsini, Laboratory of Toxicology, Department of Pharmacological Sciences, Via Balzaretti 9, 20133 Milan, Italy. Tel: 390250318368. Fax: 390250318284. emanuela.corsini@ unimi.it.

Declaration of interest

The Authors declare of not having any financial, personal, or association with any of individuals or organizations that could have inappropriately influence the submitted work. The Authors alone are responsible for the content and writing of the paper. This article may be the work product of an employee or group of employees of the National Institute of Environmental Health Sciences (NIEHS), National Institutes of Health (NIH); however, the statements, opinions or conclusions contained therein do not necessarily represent the statements, opinions or conclusions of NIEHS, NIH or the United States government. 


\section{Keywords}

Regulatory T-cells; immunosuppression; allergy; autoimmunity

\section{Introduction}

The existence of suppressor T-cells and their role in the maintenance of immune homeostasis was first proposed in the early 1970s (Gershon and Kondo, 1971). The rediscovery of suppressor T-cells as regulatory T-cells $\left(T_{\text {regs }}\right)$ took place in the 1990s, and it is now fully accepted that distinct $\mathrm{CD} 4^{+} \mathrm{T}$-cell subtypes, discriminated on the basis of phenotype or cytokine secretion, play a critical role in maintenance of self-tolerance (Bloom et al., 1992; Sakaguchi and Powrie, 2007). $\mathrm{T}_{\text {regs }}$ are a specialized subpopulation of T-cells critical in the modulation of immune responses and in the maintenance of T-cell homeostasis and self-tolerance (Figure 1). There are several types of $\mathrm{T}_{\text {regs }}$, including natural, T-helper $\left(\mathrm{T}_{\mathrm{H}}\right.$ )-3 and T-regulatory $\left(\mathrm{T}_{\mathrm{r}}\right.$ )-1 subsets (Bach, 2003) as well as $\mathrm{CD} 8^{+} \mathrm{T}_{\text {regs }}$ (Filaci, 2007; Funatake et al., 2008; Dinesh, 2010).

Natural $\mathrm{T}_{\text {regs }}$ are generated in the thymus as a part of thymic selection as well as in the periphery in response to antigen exposure. Natural $\mathrm{T}_{\text {regs }}$ account for $\approx 5-10 \%$ of the total $\mathrm{CD} 4^{+} \mathrm{T}$-cells in the periphery; they express CD4, high levels of CD25 and are also positive for the transcriptional repression factor fork-head box P3 (FoxP3). They are essential for the prevention of autoimmunity and keeping the immune response under control (Sakaguchi et al., 2006) as their absence results in multi-organ autoimmune disease in both mice and humans. Adaptive or induced $\mathrm{T}_{\text {regs }}$ are regulatory cells that develop in the periphery, and include $\mathrm{T}_{\mathrm{r}} 1$ and $\mathrm{T}_{\mathrm{H}} 3$ cells that are $\mathrm{CD}^{+}{ }^{+} \mathrm{CD} 25^{-} \mathrm{FoxP}^{-}$. These $\mathrm{T}_{\text {regs }}$ secrete interleukin (IL)-10 and transforming growth factor (TGF)- $\beta$, and regulate immune responses. It has been suggested that in contrast to naturally occurring CD $4^{+} \mathrm{CD} 25^{+} \mathrm{T}_{\text {regs }}$, these cells represent altered states of differentiation rather than a unique cell lineage (Jonuleit and Schmitt, 2003). $\operatorname{Tr}_{1}$ cells are defined by their ability to produce large amounts of IL-10 and low to moderate levels of TGF $\beta$, whereas $\mathrm{T}_{\mathrm{H}} 3$ cells produce preferentially TGF $\beta$. In vitro stimulation of $\mathrm{CD}^{+} \mathrm{CD} 25^{-}$FoxP3 $3^{-}$cells with TGF $\beta$ induces them to express FoxP3 and secrete TGF $\beta$. They contribute to the development of antigen-specific immunosuppressive responses (Roncarolo and Levings, 2000). Immunoregulatory $\mathrm{CD} 8^{+} \mathrm{CD} 28^{-} \mathrm{T}_{\text {regs }}$ are present and functional in many human tumors, being able to inhibit both T-cell proliferation and cytotoxicity (Filaci, 2007). Data are accumulating showing the potential role of CD8 ${ }^{+} \mathrm{T}_{\text {regs }}$ in other diseases, including chronic infection and autoimmunity (Dinesh, 2010).

The constitutive expression of $\mathrm{CD} 25$ has been considered to be a characteristic feature in the identification of $\mathrm{T}_{\text {regs }}$; however, activated $\mathrm{T}$-cells also up-regulate $\mathrm{CD} 25 . \mathrm{CD} 4{ }^{+} \mathrm{CD} 25^{-} \mathrm{T}$ cells that express FoxP3 have been demonstrated during immune responses associated with bacterial infection (Fontenot et al., 2005). The expression of FoxP3 is therefore the most definitive marker to identify $\mathrm{T}_{\text {regs. }}$. CD25 and FoxP3 are also expressed by $\mathrm{CD} 8^{+} \mathrm{T}_{\text {regs }}$. Down-regulation of CD127, a subunit of the IL7R, is another mechanism to identify $\mathrm{T}_{\text {regs }}$ as it is generally accepted that the $\mathrm{CD} 25^{\text {high }} / \mathrm{CD} 127^{\text {low/- }}$ phenotype is specific to these cells (Liu et al., 2006).

The balance between activated effector cells and $\mathrm{T}_{\text {regs }}$ is important for efficient immune responses. Just as important as mounting an immune response, organisms have to control the magnitude and duration of the response. Suppression of $T_{\text {reg }}$ function and/or number may lead to unchecked immune responses resulting in autoimmune diseases, allergies, transplant rejection, maternal intolerance of fetal alloantigens, septic shock and chronic inflammation (Kondelkova et al., 2010). Enhancement of regulatory T-cell functions is a therapeutic goal 
for the treatment of many autoimmune diseases, and therapeutics such as rapamycin and its derivatives, and corticosteroids have been shown to expand $\mathrm{T}_{\text {regs }}$ (Smith and Kumar 2008; Powell and Delgoffe, 2010; Stary et al., 2011). Murine $\mathrm{T}_{\text {regs }}$ are more resistant than effector T-cells to the apoptotic effects of dexamethasone in vitro and treatment of mice with dexamethasone results in an increased proportion of $\mathrm{T}_{\text {regs }}$ in immune tissues (Chen et al., 2004). A $T_{\text {reg }}$ suppression of inflammatory responses can be both a desired and undesired effect depending on the disease. There is growing evidence that the suppressive effects of $\mathrm{T}_{\text {regs }}$ may contribute to tumor growth (Colombo and Piconese, 2007), and to poor responses to infectious agents and vaccines (Rouse et al., 2006). Therefore, the ability of xenobiotics to inhibit or activate/expand $\mathrm{T}_{\text {regs }}$ may represent a relevant mechanism underlying chemicalinduced immunotoxicity (Fort and Narayanan, 2010).

As part of the $49^{\text {th }}$ Annual Meeting of the Society of Toxicology in 2010, a symposium entitled 'Alterations in Regulatory T-Cells: Novel Pathways to Immunotoxicology' was convened to explore the role that $\mathrm{T}_{\text {regs }}$ may play in chemical-induced immunotoxicity. The Symposium started with an 'Introduction to the role of $\mathrm{T}_{\text {regs }}$ in immunity' by Mohamed Oukka, and was followed by presentations on 'Role of immunoregulatory cells in chemical and protein allergy' by Raymond Pieters, 'Induction of AHR-dependent $\mathrm{T}_{\text {regs: }}$ : A novel pathway for TCDD immunotoxicity' by Nancy Kerkvliet, and 'Safety assessment of immunomodulatory biologics post-TGN1412: The promise and challenges of regulatory Tcell modulation' by Rafael Ponce. The purpose of this review article is to highlight the role of regulatory T-cells in allergy and in 2,3,7,8-tetrachlorodibenzo- $p$-dioxin (TCDD)-induced immunosuppression; a separate paper will deal with the pharmacological modulation of regulatory T-cells.

\section{Role of immunoregulatory cells at sites of exposure}

The identification of $\mathrm{T}_{\text {regs }}$ capable of suppressing responses mediated by $\mathrm{T}_{\mathrm{H}} 1$ and $\mathrm{T}_{\mathrm{H}} 2$ cells has prompted a paradigm shift in our understanding of the regulation of immune responses. Regulatory $\mathrm{T}$-cells, including $\mathrm{T}_{\mathrm{r}} 1$ and $\mathrm{T}_{\mathrm{H}} 3$, are crucial for the induction of tolerance to food antigens, and in the maintenance of tolerance at mucosal surfaces (Battaglia et al., 2006; Lan et al., 2007). The skin, the respiratory and the gastrointestinal tract are continuously exposed to a large number of antigens, representing a relentless challenge to the immune system. An appropriate immune response must be able to differentiate between harmful and innocuous antigens. To protect the host, mechanisms must be in place to prevent deleterious reactions, such as immune responses to self-antigens, immune response to food antigens in the intestine, or exaggerated immune responses to benign environmental antigens. One key adaptation to the mucosal microenvironment is the generation within, or recruitment to the mucosal surface of $\mathrm{T}_{\text {regs }}$ (Allez and Mayer, 2004). Disturbance of normal immunoregulatory processes at mucosal surfaces, i.e., the breaking of tolerance, may occur, resulting in sensitization to chemicals, certain pharmaceuticals and food or airborne proteins.

Key components of the mucosal microenvironment include the luminal surface, epithelial cells, the lamina propria, and mucosal-associated lymphoid tissues (MALT), which can be found within the mucosal layers. The mucosal epithelium forms a tight protective barrier facilitated by integral membrane proteins and adhesion molecules, while the thick mucous secreted by specialized epithelial cells such as goblet cells provides another important barrier. Beneath the epithelial barrier, the lamina propria plays a critical role in host defense with its network of capillaries and lymphatics.

Communication is constantly established between the external environment and the host immune system. Mucosal epithelial cells actively participate in mucosal immunity through production of anti-microbial peptides, chemokines, and cytokines, and are equipped with pattern recognition receptors (PRRs) including Toll-like receptors and nucleotide-binding 
oligomerization domain (NOD) receptors: such cells also have antigen-presenting capability (Kunisawa et al., 2007).

\section{Functional and customized $\mathrm{T}_{\text {reg }}$ cells}

Naïve $\mathrm{CD}^{+} \mathrm{T}$-cells can differentiate into many different subsets of $\mathrm{T}_{\mathrm{H}}$ effector cells, notably $\mathrm{T}_{\mathrm{H}} 1, \mathrm{~T}_{\mathrm{H}} 2, \mathrm{~T}_{\mathrm{H}} 9$, and $\mathrm{T}_{\mathrm{H}} 17$ cells. The functional specialization of these various $\mathrm{CD}^{+}$ $\mathrm{T}$-cell subsets is due to the differential expression of 'master' transcription factors, namely retinoic acid receptor-related orphan receptor- $\gamma \mathrm{t}(\mathrm{ROR} \gamma \mathrm{t})$, T-bet, and GATA-binding protein 3 (GATA3), which turn on distinct programs of gene expression that control T-cell function and migration (Littman and Rudensky, 2010). However, each of these responses is pro-inflammatory and, in some circumstances, can damage tissues and lead to autoimmunity. Furthermore, $\mathrm{T}_{\mathrm{H}} 1, \mathrm{~T}_{\mathrm{H}} 2$, and $\mathrm{T}_{\mathrm{H}} 17$ cells express various chemokine receptors that help guide these cells into appropriate tissues in which these cells are needed to fight various pathogens.

Recently, several groups demonstrated that $\mathrm{T}_{\text {reg }}$ cells are not all created equal; various natural-occurring $\mathrm{T}_{\text {reg }}$ subsets exist and express transcriptional factors and chemokine receptors commonly found in either $\mathrm{T}_{\mathrm{H}} 1$ or $\mathrm{T}_{\mathrm{H}} 17$ cells (Chaudhry et al., 2009; Koch et al., 2009; Zheng et al., 2009). These $T_{\text {regs }}$ are rather specialized in preferentially suppressing $\mathrm{T}_{\mathrm{H}} 1$ or $\mathrm{T}_{\mathrm{H}} 17$ cells. $\mathrm{T}$-bet is the master transcription factor controlling the differentiation, migration, and function of interferon (IFN)- $\gamma$-producing $\mathrm{T}_{\mathrm{H}} 1$ cells (Szabo et al., 2000). Interestingly, $\mathrm{T}$-bet is also expressed by a subset of $\mathrm{T}_{\text {reg }}$ cells, and is required for $\mathrm{T}_{\text {reg }}$ cell homeostasis and function during polarized $\mathrm{T}_{\mathrm{H}} 1$-type immune response (Koch et al., 2009). Finally, deletion of signal transducer and activation of transcription-3 (STAT3) in $\mathrm{T}_{\text {reg }}$ cells results in the development of a spontaneous fatal intestinal inflammation that is characterized by excessive IL-17 production, but normal levels of $\mathrm{T}_{\mathrm{H}} 1$-associated inflammatory cytokines; this indicates that there is selective dysregulation of $\mathrm{T}_{\mathrm{H}}$ 17-type responses in the absence of STAT3-expressing $\mathrm{T}_{\text {reg }}$ cells (Chaudhry et al., 2009). The mechanisms by which T-bet and STAT3 control $\mathrm{T}_{\text {reg }}$ cell activity during $\mathrm{T}_{\mathrm{H}} 1, \mathrm{~T}_{\mathrm{H}} 2$, and $\mathrm{T}_{\mathrm{H}} 17$ cell-mediated responses are still unclear, but are likely to involve a combination of influences on $\mathrm{T}_{\text {reg }}$ cell migration, function and homeostasis. Additionally, loss of these transcription factors may affect the functional properties of $\mathrm{T}_{\text {reg }}$ cells.

From these data, a model emerges in which selective expression or activation of transcriptional regulators associated with $\mathrm{T}_{\mathrm{H}} 1, \mathrm{~T}_{\mathrm{H}} 2$, and $\mathrm{T}_{\mathrm{H}} 17$ cells drives the phenotypical and functional specialization of $\mathrm{T}_{\text {reg }}$ cells, and the expression of subset of specific genes needed to restrain these different types of $\mathrm{CD} 4^{+} \mathrm{T}$-cell responses.

\section{Role of immunoregulatory cells in chemical and protein allergy}

As early as 1970, studies in guinea pigs demonstrated that dermal sensitization to 2,4dintrochlorobenzene (DNCB) is subject to tolerance induction by oral pre-exposure to DNCB (Lowney, 1971). In rodents, tolerance induction could be prevented by cyclophosphamide, which has been shown to inhibit $\mathrm{T}_{\text {regs }}$ (Ikezawa et al., 2005). Subsequently, in the 1980s and 1990s, the mechanisms regulating sensitization became clearer through studies using multiple rat strains to examine autoimmune phenomena, particularly following exposure to mercuric chloride (Pelletier et al., 1988, 1990; Mathieson et al., 1991; Kosuda et al., 1994). Brown Norway rats recovering from mercury induced autoimmunity became resistant to disease induction upon re-exposure to the same compound. A similar phenomenon was observed in rats treated with and then re-exposed to D-penicillamine (Masson et al., 2004; Seguin et al., 2004) and nevirapine (Shenton et al., 2003). In mice, similar immunoregulatory processes were found to occur in response to procainamide (Layland et al., 2004), nickel (Roelofs-Haarhuis et al., 2004), and contact 
sensitizers such as DNCB (Ju et al., 2003). Adoptive transfer and/or depletion of specific Tcell populations in these rodent models of allergy and autoimmunity reinforced the concept that active regulation by $\mathrm{CD} 4^{+}$and $\mathrm{CD} 8^{+} \mathrm{T}$-cells is one of the key mechanisms for the maintenance of self-tolerance and protection from sensitization and self-reactivity (Field et al., 2003; Roelofs-Haarhuis et al., 2004; Seguin et al., 2004; Shenton et al., 2005).

Additional regulatory mechanisms for compounds that induce hypersensitivity include NK$\mathrm{T}$ cells, dendritic cells (DC), and Kupffer cells. When activated, these cells have been shown to induce and/or expand $\mathrm{T}_{\text {reg }}$ (Ju et al., 2003; Roelofs-Haarhuis et al., 2004). Tolerance, and induction of regulatory mechanisms to protein allergens, is dependent on route of exposure, dose, genotype, gender, and age (neonatal tolerance; Field et al., 2000, 2003). Oral exposure can induce anergic T-cells with regulatory activity (Artik et al., 2001) and the presence of commensal organisms, $\mathrm{CD}^{+}$intraepithelial lymphocytes, and $\mathrm{DC}$ in the gut foster a tolerogenic environment (Weiner et al., 2011). It has been suggested that low dose oral exposure to protein allergens favors the induction of $\mathrm{T}_{\text {regs }}$, whereas higher doses favor the induction of anergy or deletion of reactive T-cells (Weiner et al., 2011). Low dose oral tolerance has been shown to prevent mercury induced autoimmune disease (Szeto et al., 1999; Pelletier et al., 1990; Mathieson et al., 1991) with both compound-specific and nonspecific T-cell regulation described (Layland et al., 2004). For example, CD8 ${ }^{+}$suppressor cells from mercuric chloride-exposed rats appear to act through similar regulatory cytokines as has been described for $\mathrm{CD}^{+} \mathrm{T}_{\text {regs }}$, i.e., TGF $\beta$ and IL-10, as well as via IFN $\gamma$ - and receptormediated regulation (e.g., CTLA-4).

Orally-induced tolerance is of particular relevance in case of food allergy, where there is a lack of tolerance and proper immunoregulation to specific proteins (Mowat et al., 2003). Several mouse studies with food allergens indicate that $\mathrm{CD} 25^{+} \mathrm{T}_{\text {regs }}$ are at least of some importance in preventing responses to peanut (van Wijk et al., 2007) and milk proteins (Schouten et al., 2010). However, other regulatory processes may also be involved, including IFN $\gamma$-producing cells, other regulatory T-cells (Rezende, 2011), g $\delta$ T-cells (BolSchoenmakers et al., 2011), and regulatory mucosal DC (Smit et al., 2011).

\section{Induction of AhR-dependent $\mathrm{T}_{\text {regs }}$ : A novel pathway for TCDD immunotoxicity}

TCDD is an aryl hydrocarbon receptor (AhR) ligand that induces immunosuppression in experimental animals, including thymic involution, decreased antibody production and cytotoxic T-lymphocyte development, and increased susceptibility to a variety of infectious diseases (Kerkvliet et al., 2002). It has been shown that the immunosuppressive effect of TCDD in mice correlated with $\mathrm{CD} 25^{+} \mathrm{CD} 4{ }^{+}$regulatory T-cell generation (Funatake et al., 2005; Kerkvliet et al., 2009).

Like natural $\mathrm{T}_{\text {regs }}$, TCDD-derived CD4 ${ }^{+} \mathrm{T}$-cells did not produce IL-2 and their suppressive function was contact dependent (Marshall et al., 2008). Depending on the experimental model, TCDD-derived $\mathrm{T}_{\text {regs }}$ tended to secrete significant amounts of IL-10 or TGF $\beta$ in response to both polyclonal and allogeneic stimuli (Marshall et al., 2008; Quintana et al., 2008). Interestingly, in one study, exposure of murine immune cells to 6-formylindolo(3,2b) carbazole (another AhR ligand) in combination with TGF $\beta$ resulted in the formation of pro-inflammatory IL-17-secreting T-cells, that could exacerbate inflammation in vivo (Quintana et al., 2008).

It remains to be determined whether the generation of IL-10- or TGF $\beta$-producing $\mathrm{CD}^{+} \mathrm{T}$ cells is a major component of TCDD-induced immunosuppression in experimental animals. Proposed mechanisms by which AhR signaling might promote $\mathrm{T}_{\text {reg }}$ differentiation include reduction in CD62L expression in T-cells (Funatake et al., 2004, 2005), regulation of FoxP3 expression (Quintana et al., 2008; Hauben et al., 2008; Kimura et al., 2008), and/or 
modulation of DC antigen presentation. Antigen presentation by DC plays a key role in converting naïve T-cells into adaptive $\mathrm{T}_{\text {regs }}$. TCDD-induced activation of the AhR causes an increase in CTLA-4 expression in T-cells that may induce tolerogenic DC (Funatake et al., 2005). In the absence of the appropriate cytokines, DC can induce clonal deletion, anergy or tolerogenic regulatory T-cells (Vorderstrasse and Kerkvliet, 2001; Thorstenson and Khoruts, 2001; Yamazaki et al., 2006). In addition, signaling through the AhR may up-regulate TGF $\beta$ signaling, promoting the expansion and function of $\mathrm{T}_{\text {regs }}$ (Huber et al., 2004).

The AhR has also been reported to play a role in the development of $\mathrm{T}_{\mathrm{H}} 17$ cells (Quintana et al., 2008; Veldhoen et al., 2008a). $\mathrm{T}_{\mathrm{H}} 17$ cells are characterized by their secretion of proinflammatory cytokines IL-17 and IL-22. The ligand-activated AhR regulates expression of these cytokines in tissue culture. A role for the AhR in the regulation of $T_{H} 17$ cells is supported further by the observation that the absolute number of $\mathrm{T}_{\mathrm{H}} 17$ cells is reduced in AhR null mice upon induction of Experimental Autoimmune Encephalomyelitis (Veldhoen et al., 2008b). Because $\mathrm{T}_{\mathrm{H}} 17$ cells promote the immune response and $\mathrm{T}_{\text {regs }}$ are known to decrease immune reactivity, a model has emerged suggesting that the $T_{\text {reg }} / T_{H} 17$ balance distinguishes an effective immune response and self-antigen tolerance from chronic infection or autoimmunity. Preliminary evidence from multiple laboratories has suggested that the AhR modifies the $T_{\text {reg }} / T_{H} 17$ cell balance through modifying the cytokine milieu. The mechanism at work may be related to the fact that TGF $\beta$ induces $T_{\text {reg }}$ differentiation, while the presence of IL- 6 leads to TGF $\beta$-dependent $T_{H} 17$ cell production. Elucidating the specific transcriptional targets of the AhR that result in the induction of $\mathrm{T}_{\text {regs }}$ through the used of potent and specific AhR ligands such as TCDD that may provide the most direct route to understand signaling steps by which the AhR influences the immune system.

\section{Concluding remarks}

The concept of regulatory or suppressor cells having a role in chemical-induced immune system toxicology has been somewhat understudied. However, it is now recognized that $\mathrm{T}_{\text {regs }}$ play a critical role in maintaining the careful balancing act that allows the immune system to respond appropriately in the face of infection or disease, resolve when the challenge has diminished, and fail to respond to self-antigens. As shown by the speakers in this symposium, various immunoregulatory T-cell subsets may be induced by environmental chemicals and protein allergens. Chemical-induced alterations in $\mathrm{T}_{\text {regs }}$ number or function may be of pivotal importance in the clinical outcomes following chemical exposure and further research is needed to elucidate the role of $\mathrm{T}_{\text {regs }}$ in chemical-induced modulation of immune function and how this may impact human health and the burden of disease.

\section{References}

Allez M, Mayer L. Regulatory T cells: Peace keepers in the gut. Inflamm Bowel Dis. 2004; 10:666676. [PubMed: 15472533]

Artik S, Haarhuis K, Wu X, Begerow J, Gleichmann E. Tolerance to nickel: Oral nickel administration induces a high frequency of anergic T-cells with persistent suppressor activity. J Immunol. 2001; 167:6794-6803. [PubMed: 11739495]

Bach JF, François Bach J. Regulatory T-cells under scrutiny. Nat Rev Immunol. 2003; 3:189-198. [PubMed: 12658267]

Battaglia M, Gregori S, Bacchetta R, Roncarolo MG. $\mathrm{T}_{\mathrm{r}} 1$ cells: From discovery to their clinical application. Semin Immunol. 2006; 18:120-127. [PubMed: 16464609]

Bloom BR, Salgame P, Diamond B. Revisiting and revising suppressor T-cells. Immunol Today. 1992; 13:131-136. [PubMed: 1533765]

Bol-Schoenmakers M, Marcondes Rezende M, Bleumink R, Boon L, Man S, Hassing I, Fiechter D, Pieters RH, Smit JJ. Regulation by intestinal g $\delta$ T-cells during establishment of food allergic sensitization in mice. $2011 ; 66: 331-340$. 
Chaudhry A, Rudra D, Treuting P, Samstein RM, Liang Y, Kas A, Rudensky AY. CD4 ${ }^{+}$regulatory Tcells control $\mathrm{Th}^{17}$ responses in a Stat3-dependent manner. 2009; 326:986-991.

Chen X, Murakami T, Oppenheim JJ, Howard OM. Differential response of murine CD4 $4^{+} \mathrm{CD} 25^{+}$and $\mathrm{CD}^{+} \mathrm{CD} 25^{-}$T-cells to dexamethasone-induced cell death. Eur J Immunol. 2004; 34:859-869. [PubMed: 14991616]

Colombo MP, Piconese S. Regulatory-T-cell inhibition versus depletion: The right choice in cancer immunotherapy. Nat Rev. 2007; 7:880-887.

Dinesh RK, Skaggs BJ, La Cava A, Hahn BH, Singh RP. CD8 ${ }^{+}$Tregs in lupus, autoimmunity, and beyond. Autoimmun Rev. 2010; 9:560-568. [PubMed: 20385256]

Field AC, Caccavelli L, Bloch MF, Bellon B. Regulatory CD8 ${ }^{+}$T-cells control neonatal tolerance to a Th2-mediated autoimmunity. J Immunol. 2003; 170:2508-2515. [PubMed: 12594276]

Field AC, Caccavelli L, Fillion J, Kuhn J, Mandet C, Druet P, Bellon B. Neonatal induction of tolerance to $\mathrm{T}(\mathrm{h})^{2}$-mediated autoimmunity in rats. Int Immunol. 2000; 12:1467-1477. [PubMed: 11007765]

Filaci G, Fenoglio D, Fravega M, Ansaldo G, Borgonovo G, Traverso P, Villaggio B, Ferrera A, Kunkl A, Rizzi M, Ferrera F, Balestra P, Ghio M, Contini P, Setti M, Olive D, Azzarone B, Carmignani G, Ravetti JL, Torre G, Indiveri F. CD8 ${ }^{+}$CD28- T-regulatory lymphocytes inhibiting T-cell proliferative and cytotoxic functions infiltrate human cancers. J Immunol. 2007; 179:4323-4334. [PubMed: 17878327]

Fontenot JD, Rasmussen JP, Williams LM, Dooley JL, Farr AG, Rudensky AY. Regulatory T-cell lineage specification by the forkhead transcription factor FoxP3. 2005; 22:329-341.

Fort MM, Narayanan PK. Manipulation of regulatory T-cell function by immunomodulators: A boon or a curse? Toxicol Sci. 2010; 117:253-262. [PubMed: 20484381]

Funatake CJ, Dearstyne EA, Steppan LB, Shepherd DM, Spanjaard ES, Marshak-Rothstein A, Kerkvliet NI. Early consequences of 2,3,7,8-tetrachlorodibenzo- $p$-dioxin exposure on the activation and survival of antigen-specific T-cells. Toxicol Sci. 2004; 82:129-142. [PubMed: 15310856]

Funatake CJ, Marshall NB, Kerkvliet NI. 2,3,7,8-Tetrachlorodibenzo-p-dioxin alters the differentiation of alloreactive CD8+ T-cells toward a regulatory T-cell phenotype by a mechanism that is dependent on aryl hydrocarbon receptor in CD4+ T-cells. J Immunotoxicol. 2008; 5:81-91. [PubMed: 18382861]

Funatake CJ, Marshall NB, Steppan LB, Mourich DV, Kerkvliet NI. Cutting edge: Activation of the aryl hydrocarbon receptor by 2,3,7,8-tetrachlorodibenzo- $p$-dioxin generates a population of $\mathrm{CD}^{+}$ CD $25^{+}$cells with characteristics of regulatory T-cells. J Immunol. 2005; 175:4184-4188. [PubMed: 16177056]

Gershon RK, Kondo K. Infectious immunological tolerance. Immunology. 1971; 21:903-914. [PubMed: 4943147]

Hauben E, Gregori S, Draghici E, Migliavacca B, Olivieri S, Woisetschläger M, Roncarolo MG. Activation of the aryl hydrocarbon receptor promotes allograft-specific tolerance through direct and dendritic cell-mediated effects on regulatory T-cells. Blood. 2008; 112:1214-1222. [PubMed: 18550851]

Huber S, Schramm C, Lehr HA, Mann A, Schmitt S, Becker C, Protschka M, Galle PR, Neurath MF, Blessing M. Cutting edge: TGF- $\beta$ signaling is required for the in vivo expansion and immunosuppressive capacity of regulatory CD4+CD25+ T-cells. J Immunol. 2004; 173:65266531. [PubMed: 15557141]

Ikezawa Y, Nakazawa M, Tamura C, Takahashi K, Minami M, Ikezawa Z. Cyclophosphamide decreases the number, percentage and the function of $\mathrm{CD} 25^{+} \mathrm{CD} 4^{+}$regulatory T-cells, which suppress induction of contact hypersensitivity. J Dermatol Sci. 2005; 39:105-112. [PubMed: 15899580]

Jonuleit H, Schmitt E. The regulatory T-cell family: Distinct subsets and their interrelations. J Immunol. 2003; 171:6323-6327. [PubMed: 14662827]

Ju C, McCoy JP, Chung CJ, Graf ML, Pohl LR. Tolerogenic role of Kupffer cells in allergic reactions. Chem Res Toxicol. 2003; 16:1514-1519. [PubMed: 14680364] 
Kerkvliet NI. Recent advances in understanding the mechanisms of TCDD immunotoxicity. Int Immunopharmacol. 2002; 2:277-291. [PubMed: 11811931]

Kerkvliet NI, Steppan LB, Vorachek W, Oda S, Farrer D, Wong CP, Pham D, Mourich DV. Activation of aryl hydrocarbon receptor by TCDD prevents diabetes in NOD mice and increases FoxP3 ${ }^{+} \mathrm{T}$ cells in pancreatic lymph nodes. Immunotherapy. 2009; 1:539-547. [PubMed: 20174617]

Kimura A, Naka T, Nohara K, Fujii-Kuriyama Y, Kishimoto T. Aryl hydrocarbon receptor regulates Stat 1 activation and participates in the development of TH17 cells. Proc Natl Acad Sci USA. 2008; 105:9721-9726. [PubMed: 18607004]

Koch MA, Tucker-Heard G, Perdue NR, Killebrew JR, Urdahl KB, Campbell DJ. The transcription factor T-bet controls regulatory T-cell homeostasis and function during type 1 inflammation. Nat Immunol. 2009; 10:595-602. [PubMed: 19412181]

Kondelková K, Vokurková D, Krejsek J, Borská L, Fiala Z, Ctirad A. Regulatory T-cells (Treg) and their roles in immune system with respect to immunopathological disorders. Acta Medica (Hradec Kralove). 2010; 53:73-77. [PubMed: 20672742]

Kosuda LL, Hosseinzadeh H, Greiner DL, Bigazzi PE. Role of RT6 ${ }^{+}$T-lymphocytes in mercuryinduced renal autoimmunity: Experimental manipulations of "susceptible" and "resistant" rats. J Toxicol Environ Health. 1994; 42:303-321. [PubMed: 8021964]

Kunisawa J, Takahashi I, Kiyono H. Intraepithelial lymphocytes: Their shared and divergent immunological behaviors in the small and large intestine. Immunol Rev. 2007; 215:136-153. [PubMed: 17291285]

Lan RY, Mackay IR, Gershwin ME. Regulatory T-cells in the prevention of mucosal inflammatory diseases: Patrolling the border. J Autoimmun. 2007; 29:272-280. [PubMed: 17889505]

Layland LE, Wulferink M, Dierkes S, Gleichmann E. Drug-induced autoantibody formation in mice: Triggering by primed $\mathrm{CD} 4^{+} \mathrm{CD} 25^{-} \mathrm{T}$-cells, prevention by primed $\mathrm{CD} 4^{+} \mathrm{CD} 25^{+} \mathrm{T}$-cells. Eur $\mathrm{J}$ Immunol. 2004; 34:36-46. [PubMed: 14971028]

Littman DR, Rudensky AY. TH17 and regulatory T-cells in mediating and restraining inflammation. Cell. 2010; 140:845-858. [PubMed: 20303875]

Liu W, Putnam AL, Xu-Yu Z, Szot GL, Lee MR, Zhu S, Gottlieb PA, Kapranov P, Gingeras TR, Fazekas de St Groth B, Clayberger C, Soper DM, Ziegler SF, Bluestone JA. CD127 expression inversely correlates with FoxP3 and suppressive function of human CD4 ${ }^{+}$Treg cells. J Exp Med. 2006; 203:1701-1711. [PubMed: 16818678]

Lowney ED. Tolerance of dinitrochlorobenzene, a contact sensitizer, in man. J Allergy Clin Immunol. 1971; 48:28-35. [PubMed: 5282886]

Marshall NB, Vorachek WR, Steppan LB, Mourich DV, Kerkvliet NI. Functional characterization and gene expression analysis of $\mathrm{CD} 4^{+} \mathrm{CD} 25^{+}$regulatory T-cells generated in mice treated with 2,3,7,8-tetrachlorodibenzo-p-dioxin. J Immunol. 2008; 181:2382-2391. [PubMed: 18684927]

Masson MJ, Uetrecht JP. Tolerance induced by low dose D-penicillamine in the Brown Norway rat model of drug-induced autoimmunity is immune-mediated. Chem Res Toxicol. 2004; 17:82-94. [PubMed: 14727922]

Mathieson PW, Stapleton KJ, Oliveira DB, Lockwood CM. Immunoregulation of mercuric chlorideinduced autoimmunity in Brown Norway rats: A role for CD8+ T-cells revealed by in vivo depletion studies. Eur J Immunol. 1991; 21:2105-2109. [PubMed: 1909641]

Mowat AM. Anatomical basis of tolerance and immunity to intestinal antigens. Nat Rev Immunol. 2003; 3:331-341. [PubMed: 12669023]

Quintana FJ, Basso AS, Iglesias AH, Korn T, Farez MF, Bettelli E, Caccamo M, Oukka M, Weiner HL. Control of Treg and TH17 cell differentiation by the aryl hydrocarbon receptor. Nature. 2008; 453:65-71. [PubMed: 18362915]

Pelletier L, Pasquier R, Rossert J, Vial MC, Mandet C, Druet P. Autoreactive T-cells in mercuryinduced autoimmunity. Ability to induce the autoimmune disease. J Immunol. 1988; 140:750-754. [PubMed: 3257501]

Pelletier L, Rossert J, Pasquier R, Vial MC, Druet P. Role of CD8 ${ }^{+}$T-cells in mercury-induced autoimmunity or immunosuppression in the rat. Scand J Immunol. 1990; 31:65-74. [PubMed: 2137255] 
Powell JD, Delgoffe GM. The mammalian target of rapamycin: Linking T-cell differentiation, function, and metabolism. Immunity. 2010; 33:301-311. [PubMed: 20870173]

Rezende MM, Hassing I, Bol-Schoenmakers M, Bleumink R, Boon L, van Bilsen J, Pieters R. $\mathrm{CD} 4{ }^{+} \mathrm{CD} 25^{+} \mathrm{T}$-regulatory cells do not transfer oral tolerance to peanut allergens in a mouse model of peanut allergy. Clin Exp Allergy. 2011

Roelofs-Haarhuis K, Wu X, Gleichmann E. Oral tolerance to nickel requires CD4 ${ }^{+}$invariant NKTcells for the infectious spread of tolerance and the induction of specific regulatory T-cells. J Immunol. 2004; 173:1043-1050. [PubMed: 15240692]

Roncarolo MG, Levings MK. The role of different subsets of T-regulatory cells in controlling autoimmunity. Curr Opin Immunol. 2000; 12:676-683. [PubMed: 11102772]

Rouse BT, Sarangi PP, Suvas S. Regulatory T-cells in virus infections. Immunol Rev. 2006; 212:272286. [PubMed: 16903920]

Sakaguchi S, Ono M, Setoguchi R, Yagi H, Hori S, Fehervari Z, Shimizu J, Takahashi T, Nomura T. $\mathrm{FoxP}^{+} \mathrm{CD}^{+} 5^{+} \mathrm{CD} 4^{+}$natural regulatory T-cells in dominant self-tolerance and autoimmune disease. Immunol Rev. 2006; 212:8-27. [PubMed: 16903903]

Sakaguchi S, Powrie F. Emerging challenges in regulatory T-cell function and biology. Science. 2007; 317:627-629. [PubMed: 17673654]

Schouten B, van Esch BC, Hofman GA, Boon L, Knippels LM, Willemsen LE, Garssen J. Oligosaccharide-induced whey-specific $\mathrm{CD} 25^{+}$regulatory T-cells are involved in the suppression of cow milk allergy in mice. J Nutr. 2010; 140:835-841. [PubMed: 20164372]

Séguin B, Masson MJ, Uetrecht J. D-Penicillamine-induced autoimmunity in the Brown Norway rat: Role for both T- and non-T splenocytes in adoptive transfer of tolerance. Chem Res Toxicol. 2004; 17:1299-1302. [PubMed: 15487889]

Shenton JM, Teranishi M, Abu-Asab MS, Yager JA, Uetrecht JP. Characterization of a potential animal model of an idiosyncratic drug reaction: Nevirapine-induced skin rash in the rat. Chem Res Toxicol. 2003; 16:1078-1089. [PubMed: 12971795]

Smit JJ, Bol-Schoenmakers M, Hassing I, Fiechter D, Boon L, Bleumink R, Pieters RH. The role of intestinal dendritic cells subsets in the establishment of food allergy. Clin Exp Allergy. 2011; 41:890-898. [PubMed: 21477183]

Smith TR, Kumar V. Revival of CD8 ${ }^{+}$Treg-mediated suppression. Trends Immunol. 2008; 29:337342. [PubMed: 18514574]

Stary G, Klein I, Bauer W, Koszik F, Reininger B, Kohlhofer S, Gruber K, Skvara H, Jung T, Stingl G. Glucocorticosteroids modify Langerhans cells to produce TGF $\beta$ and expand regulatory T-cells. J Immunol. 2011; 186:103-112. [PubMed: 21135170]

Stevens EA, Mezrich JD, Bradfield CA. The aryl hydrocarbon receptor: A perspective on potential roles in the immune system. Immunology. 2009; 127:299-311. [PubMed: 19538249]

Szabo SJ, Kim ST, Costa GL, Zhang X, Fathman CG, Glimcher LH. A novel transcription factor, Tbet, directs TH1 lineage commitment. Cell. 2000; 100:655-669. [PubMed: 10761931]

Szeto C, Gillespie KM, Mathieson PW. Low-dose mercuric chloride induces resistance in Brown Norway rats to further mercuric chloride by up-regulation of interferon- $\gamma$. Scand J Immunol. 1999; 50:195-201. [PubMed: 10447925]

Thorstenson KM, Khoruts A. Generation of anergic and potentially immunoregulatory CD $25^{+} \mathrm{CD} 4^{+}$ T-cells in vivo after induction of peripheral tolerance with intravenous or oral antigen. J Immunol. 2001; 167:188-195. [PubMed: 11418648]

van Wijk F, Wehrens EJ, Nierkens S, Boon L, Kasran A, Pieters R, Knippels LM. CD4+CD25+ Tcells regulate the intensity of hypersensitivity responses to peanut, but are not decisive in the induction of oral sensitization. Clin Exp Allergy. 2007; 37:572-581. [PubMed: 17430355]

Veldhoen M, Hirota K, Christensen J, O'Garra A, Stockinger B. Natural agonists for aryl hydrocarbon receptor in culture medium are essential for optimal differentiation of TH17 T-cells. J Exp Med. 2009a; 206:43-49. [PubMed: 19114668]

Veldhoen M, Hirota K, Westendorf AM, Buer J, Dumoutier L, Renauld JC, Stockinger B. The aryl hydrocarbon receptor links TH17-cell-mediated autoimmunity to environmental toxins. Nature. 2008b; 453:106-109. [PubMed: 18362914] 
Vorderstrasse BA, Kerkvliet NI. 2,3,7,8-Tetrachlorodibenzo- $p$-dioxin affects the number and function of murine splenic dendritic cells and their expression of accessory molecules. Toxicol Appl Pharmacol. 2001; 171:117-125. [PubMed: 11222087]

Weiner HL, da Cunha AP, Quintana F, Wu H. Oral tolerance. Immunol Rev. 2011; 241:241-259. [PubMed: 21488901]

Yamazaki S, Inaba K, Tarbell KV, Steinman RM. Dendritic cells expand antigen-specific FoxP $3^{+} \mathrm{CD} 25^{+} \mathrm{CD} 4^{+}$regulatory T-cells including suppressors of alloreactivity. Immunol Rev. 2006; 212:314-329. [PubMed: 16903923]

Zheng Y, Chaudhry A, Kas A, deRoos P, Kim JM, Chu TT, Corcoran L, Treuting P, Klein U, Rudensky AY. Regulatory T-cell suppressor program co-opts transcription factor IRF4 to control TH2 responses. Nature. 2009; 458:351-356. [PubMed: 19182775] 


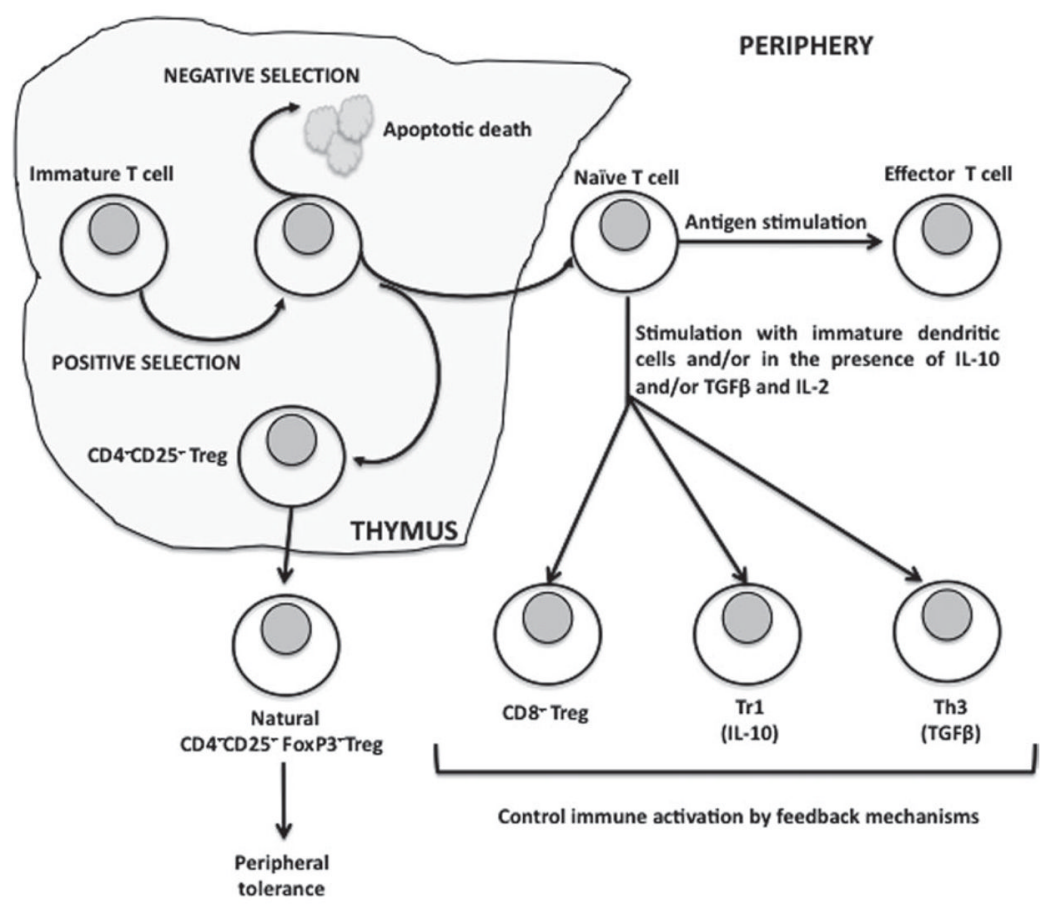

Figure 1.

Regulatory T-cells and their role in immune response. 